$\xi=$ 頤

\title{
Effect of green manure along with nitrogenous fertilizer on the growth and yield of turmeric (curcuma longa l.) of Bangladesh
}

\author{
Mahbuba Ferdous ${ }^{1}$, Mohammad Kabirul Islam ${ }^{1}$, Md. Monirul Islam ${ }^{1}$ *, Md. Isfatuzzaman Bhuyan ${ }^{2}$, \\ Md. Sazedul Islam ${ }^{1}$, Purmendu Sarkar ${ }^{3}$ \\ ${ }^{1}$ Department of Soil Science, Patuakhali Science and Technology University, Dumki, Patuakhali, Dhaka, Bangladesh \\ ${ }^{2}$ Department of Agronomy, Bangladesh Agricultural University, Mymensingh, Dhaka, Bangladesh \\ ${ }^{3}$ Department of Agronomy, Patuakhali Science and Technology University, Dumki, Patuakhali, Dhaka, Bangladesh \\ *Corresponding author E-mail: monirulpstu1@gmail.com
}

\begin{abstract}
Turmeric is an important spice crop of Bangladesh. A field experiment was conducted at farmer's field of North Jhatibunia, Mirzagonj, Patuakhali during April, 2015 to February, 2016. The study was performed to find out the effect of green manure and nitrogenous fertilizer on the growth and yield of turmeric (BARI Halud-2), in coastal region of Bangladesh. In this study different combinations of green manure along with nitrogenous fertilizer were used. There was eight treatment combinations (viz. 7 ton biomass $/ \mathrm{ha}+100 \mathrm{~kg} \mathrm{~N} / \mathrm{ha}, 7$ ton biomass/ha $+80 \mathrm{~kg} \mathrm{~N} / \mathrm{ha}, 7$ ton biomass $/ \mathrm{ha}+60 \mathrm{~kg} \mathrm{~N} / \mathrm{ha}, 7$ ton biomass $/ \mathrm{ha}+40 \mathrm{~kg} \mathrm{~N} / \mathrm{ha}, 7$ ton biomass $/ \mathrm{ha}+20 \mathrm{~kg} \mathrm{~N} / \mathrm{ha}, 7$ ton biomass $/ \mathrm{ha}, 100 \mathrm{~kg}$ $\mathrm{N} / \mathrm{ha}$ and control). The highest number of leaves per plant (11.67) were recorded by the combined application of 7 ton biomass/ha along with $100 \mathrm{~kg} \mathrm{~N} / \mathrm{ha}$. The highest plant height $(80.70 \mathrm{~cm})$ and the longest leaf length $(47.33 \mathrm{~cm})$ were recorded by the application of $100 \mathrm{~kg}$ $\mathrm{N} / \mathrm{ha}$. The highest number of tillers per plant (7.67), maximum number of primary rhizomes per plant (9.00), maximum fresh weight of clump (189.67 g), highest fresh weight of roots $(48.01 \mathrm{~g})$, maximum fresh weight of rhizomes $(277.70 \mathrm{~g})$, maximum dry weight of clump $(20.01 \mathrm{~g})$, highest dry weight of roots $(9.25 \mathrm{~g})$, maximum dry weight of rhizomes $(67.50 \mathrm{~g})$ and maximum yield of fresh rhizome per hectare (6.64 tons) were recorded by the combined application of 7 ton /ha biomass $+40 \mathrm{~kg} \mathrm{~N} / \mathrm{ha}$. Highest number of secondary rhizomes per plant (17.00) and maximum number of tertiary rhizomes per plant (7.00) were recorded by the application of 7 ton biomass $/ \mathrm{ha}+60 \mathrm{~kg} N / \mathrm{ha}$. With a few exception, the best performance in terms of growth and yield of turmeric were found from the combination of 7 ton biomass $/ \mathrm{ha}+40 \mathrm{~kg} \mathrm{~N} / \mathrm{ha}$.
\end{abstract}

Keywords: Turmeric; Green Manure; Nitrogenous Fertilizer; Bangladesh.

\section{Introduction}

Turmeric (Curcuma longa) is an important and common spice crop of Bangladesh. Many of the country consider curry to be incomplete without it. It is widely used as a spice in South Asian and Middle Eastern cooking for its natural food coloring capacity. Among the spices crops turmeric is a popular and is used in huge numbers of food items (Rahman et al., 2010). The spice is produced by boiling the rhizome, drying them to obtain the characteristic yellow color and grinding them into powder. It is also used in preparing cosmetics and is a raw material of dyeing industries. The turmeric power obtained from rhizome contain curcuminoids have medicinal properties which is used in the treatment of circulatory problems, liver diseases and blood purification (Ishimine et al., 2003). It also show antibacterial, anti-fungal, anti-ulcer and anti-cancer effect. Now it is an important herbal medicine in the world. It has strong associations with the socio-cultural and religious life of the people of the Indian subcontinent.

Turmeric is a rhizomatous herbaceous perennial plant of the ginger family, Zingiberaceae. It is native to tropical south East Asia and needs temperatures between $20^{\circ} \mathrm{C}$ and $30^{\circ} \mathrm{C}$ with annual rainfall $1500 \mathrm{~mm}$ or more. This plant grows up to $1 \mathrm{~m}$ with a short stem tufted leaf. Its flowers are yellow, between $10-15 \mathrm{~cm}$ in length and they group together in dense spikes, which appear from the end of spring until the middle session. It is ready for harvesting 7 to 10 months after planting, when the lower leaves turn yellow. The whole turmeric rhizome, with a rough, segmented skin. The rhizome is yellowish-brown with a dull orange interior that looks bright yellow when powdered. Rhizome measures $2.5-7.0 \mathrm{~cm}$ (in length), and $2.5 \mathrm{~cm}$ (in diameter) with small tuber branching off (Jaggi Lal, 2012). It contains appreciable quantities of proteins (6.3\%), lipids $(5.1 \%)$, carbohydrates $(69.4 \%)$ and fibre $(2.6 \%)$. Turmeric is rich in minerals like phosphorus, calcium, iron and vitamin A (Olejede et al., 2005).

It can be grown on different types of soils, it thrives best in welldrained, fertile, sandy and black, red or alluvial loams, rich in humus and uniform in texture with a $\mathrm{pH}$ range of 4.5-7.5. Rich loamy soils having natural drainage and irrigation facilities are the best. Turmeric cannot stand water stagnation or alkalinity. Turmeric is propagated vegetatively through rhizome. Setts (small rhizomes 5$7 \mathrm{gm}$ ) with one or two buds are used for planting and well developed healthy and disease free rhizomes are to be selected. The rhizomes should be planted 7.5-8 cm deep (Srivastava, 2015). Approximately $2500 \mathrm{~kg}$ of sets are required to one hectare (ICAR, 2015). Turmeric grows well in Nilphamari, Dinajpur, Rangpur, Khulna, 
Tangail, Mymensingh, Rangamati, Bandarban and Khagrachari districts of Bangladesh. In fact, India still enjoys the unique position of being the largest producer and exporter of turmeric in the world. In Bangladesh turmeric has been cultivated in an area of 60 thousand acres with the production is 149.6 thousand $\mathrm{M}$. Tons and the yield is 2.5 M. Tons/acre in 2011-2012 (BBS, 2013).

\section{Materials and methods}

An experiment was conducted at farmers field of North Jhatibunia of Mirzagonj, in the district of Patuakhali during the period from April, 2015 to February, 2016 to investigate on the growth and yield of turmeric (BARI Halud-2), that are suitable to cultivate in coastal region of Bangladesh with three replications under different levels of green manure along with chemical fertilizers. The details of the materials and

Methods in the present experiment are described under the following headings and sub-headings.

1) Description of the experimental site

2) Location of experimental site

Geographically, the research farm area is covered by Gangetic Tidal Flood plains within the Agro ecological Zone "AEZ- 13". This region occupies a vast area of tidal floodplain land in the south-west part of Patuakhali district. Total coverage of this region is 17066 $\mathrm{km}^{2}$ with a total land volume of 1706600 ha (when Barisal, Jhalakathi, Pirojpur, Patuakhali, and Barguna are included) where the southern coastal zone surrounded by the Sundarbans (mangrove forest).

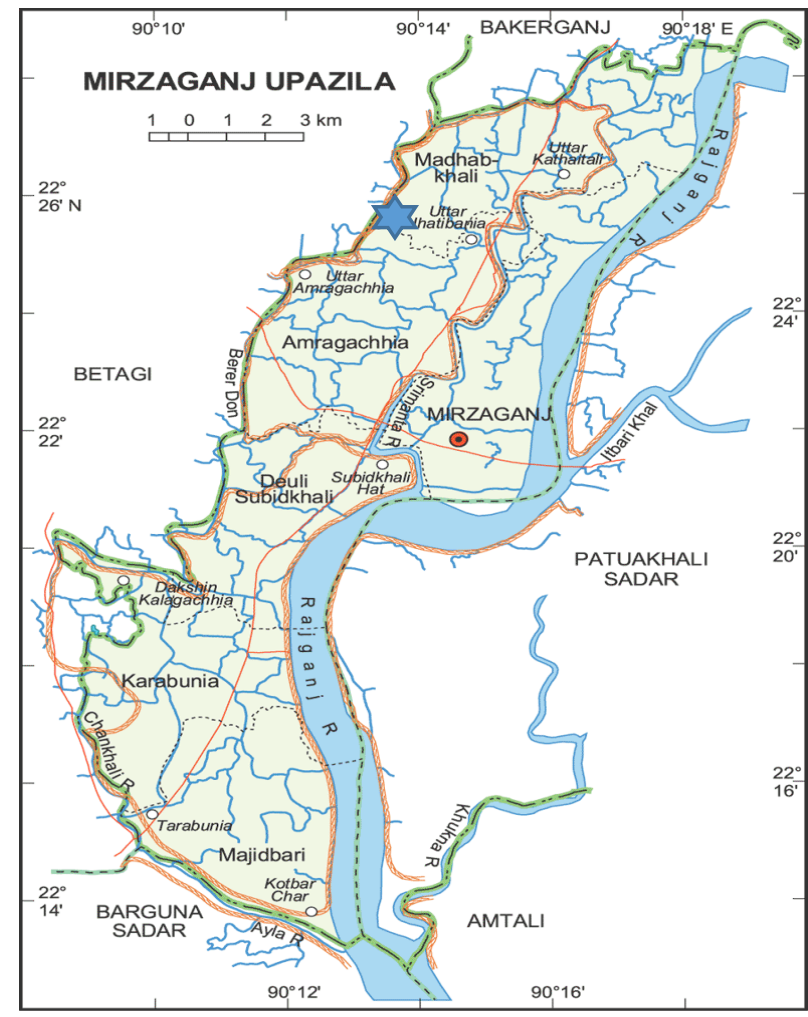

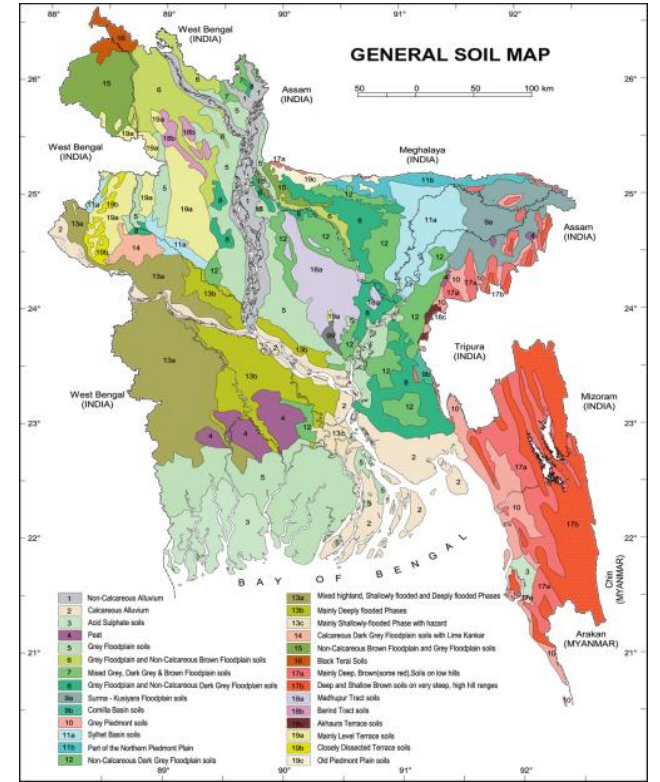

Fig. 1: Showing Location of the Experimental Area.

3) Soil of the experimental plot

Soil characteristics of the Research Farm were silty loams or alluvium. However, the soil of the experimental field was silly clay loam having $\mathrm{pH}$ value of 5.69. The characteristics of experimental soil have been presented in Table 1 . The organic matter content found $1.45 \%$ in most cases. Deficiency of nitrogen is acute and widespread. Status of exchangeable potassium is almost satisfactory.

4) Climate

Generally, Patuakhali region falls under the sub-tropical climate, which is characterized by high temperature and humidity, heavy rainfall with occasional gusty winds in the month of April to September and less rainfall associated with moderately low temperature during October to March.

5) Description of the experimental materials

6) Collection of planting materials

The setts (small rhizome) of BARI Halud-2 were collected from Breeding Division of BARI, Gazipur. The seeds were healthy, pure, well mature and free from mixture of the other seeds, weed seeds and extraneous materials.

7) Treatments of the experiment

The treatment includes different combinations of green manure along with nitrogenous fertilizers (the rate of fertilizers were at $\mathrm{kg} / \mathrm{ha}$ ) used in the experiment as follows:
i) $\mathrm{T} 1=7$ ton /ha biomass $+100 \mathrm{~kg} \mathrm{~N} / \mathrm{ha}$
ii) $\mathrm{T} 2=7$ ton $/ \mathrm{ha}$ biomass $+80 \mathrm{~kg} \mathrm{~N} / \mathrm{ha}$
iii) $\mathrm{T} 3=7$ ton /ha biomass $+60 \mathrm{~kg} \mathrm{~N} / \mathrm{ha}$
iv) $\mathrm{T} 4=7$ ton $/ \mathrm{ha}$ biomass $+40 \mathrm{~kg} \mathrm{~N} / \mathrm{ha}$
v) $\mathrm{T} 5=7$ ton $/ \mathrm{ha}$ biomass $+20 \mathrm{~kg} \mathrm{~N} / \mathrm{ha}$
vi) $\mathrm{T} 6=7$ ton /ha biomass
vii) $\mathrm{T} 7=100 \mathrm{~kg} \mathrm{~N} / \mathrm{ha}$
viii) $\mathrm{T} 8=$ Control
8) Experimental design and layout

The experiment was laid out in a Randomized Complete Block Design (RCBD) with eight treatments where each treatment consisted of three replications.

9) Green manure and fertilizers

Total amounts of green manure, phosphorus $(\mathrm{P})$ and potassium $(\mathrm{K})$ fertilizers were applied in the whole plots as basal dose during final land preparation. Nitrogen $(\mathrm{N})$ was applied in three splits, half of $\mathrm{N}$ dose was applied at 50 days after planting. Remaining $\mathrm{N}$ were applied in two equal splits at 90 and 120 days after planting. The source of N, P and K was Urea, triple super phosphate and muriate of potash, respectively.

10) Treatments of rhizome

Before planting, turmeric seeds (rhizome) were treated with Vita vex-200@0.25\% to prevent seeds from the attack of soil borne diseases. 
11) Placement of seed rhizome

The rhizomes of turmeric were placed on 25 April 2015. Rhizomes $(25 \pm 2 \mathrm{~g}$ each) were placed in rows by hand plough. Matured rhizome was placed in each hill at $7.5-8.0 \mathrm{~cm}$ depth from the soil surface.

12) Soil $\mathrm{pH}$

The glass electrode $\mathrm{pH}$ meter was used to determine the $\mathrm{pH}$ of the soil samples. The ratio of soil and water in the solution was 1:2.5.

13) EC

To determine EC of soil at first $5 \mathrm{~g}$ soil was taken in a $100 \mathrm{ml}$ beaker and then $50 \mathrm{ml}$ distilled water was added to it. It was shaken for 30 minutes and then the beaker was kept for 30 minutes for precipitation. Finally suspension was collected and measured EC by EC meter.

14) Total Nitrogen (\%)

Total Nitrogen of soil samples were determined by micro Kjeldahl method. The procedure was -digestion of soil sample by con. $\mathrm{H}_{2} \mathrm{SO}_{4}, 30 \% \mathrm{H}_{2} \mathrm{O}_{2}$ and catalyst mixture $\left(\mathrm{K}_{2} \mathrm{SO}_{4}\right.$ : $\mathrm{CuSO}_{4} .5 \mathrm{H}_{2} \mathrm{O}$ $\mathrm{Se}=10: 1: 1)$ followed by distillation with $40 \% \mathrm{NaOH}$ and by titration of the distillate trapped in $\mathrm{H}_{3} \mathrm{BO}_{3}$ with $0.01 \mathrm{~N} \mathrm{H}_{2} \mathrm{SO}_{4}$ (Black, 1965).

15) Available phosphorus

Available phosphorus content was extracted from soil with $0.5 \mathrm{M}$ $\mathrm{NaHCO}_{3}$ solution at $\mathrm{pH}$ 8.5. The phosphorus in the extract was then determined by developing blue color with $\mathrm{SnCl}_{2}$ reduction of phosphomolybdate complex and measuring the color by spectrophotometer at $660 \mathrm{~nm}$ wavelength (Page et al., 1982).

16) Available Sulphur

Available Sulphur of soil content was determined by extracting soil sample with $\mathrm{CaCl}_{2}(0.15 \%)$ solution as described by Page et al. (1982). The Sulphur content in the extract was deteraiined turbid metrically and the turbid was measured by spectrophotometer at $420 \mathrm{~nm}$ wavelength.

17) Available Potassium

At first $5 \mathrm{~g}$ soil was taken in a conical flask and $25 \mathrm{ml}$ ammonium acetate was added to it. The solution was placed to centrifuge tube and shaken for 10 minutes. Then it was centrifuged and filtered. Finally reading was observed by using flame photometer.

\section{Results and discussion}

The results of the study have been presented under the following headings and sub-headings.

\subsection{Plant height}

Different combination of green manure and nitrogenous fertilizer had significant effect on plant height .Plant height was influenced by different combination of green manure and nitrogenous fertilizer .Maximum plant height $(80.70 \mathrm{~cm})$ was observed from $100 \mathrm{~kg} \mathrm{~N} / \mathrm{ha}$ (T7) while control treatment (T8) produced minimum plant height $(51.85 \mathrm{~cm})$. All the other treatments showed an intermediate behavior compared to the maximum and minimum plant height. Nitrogen fertilizer ensured favorable condition for the growth of turmeric with optimum cell division and elongation of cell results was the tallest plant. Findings were comparable to the results of Akamine et al. (2007) and May et al. (2005). This might be due to protein synthesis by the help of nitrogen which enhance vegetative growth of turmeric plant.

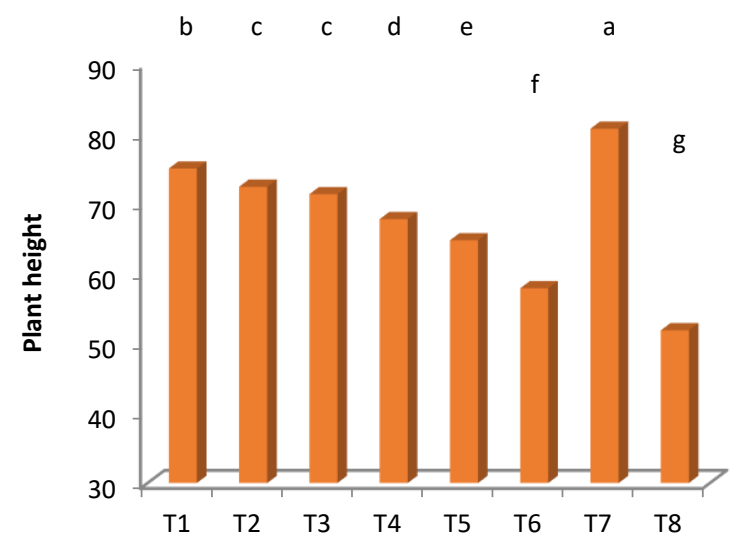

Fig. 2: Effects of Different Combination of Green Manure and Nitrogenous Fertilizer on Plant Height of Turmeric.

\subsection{Number of leaves per plant}

Significant variability was found among different levels of green manure and nitrogenous fertilizer in case of number of leaves per plant. Number of leaves was influenced by different combination of green manure and nitrogenous fertilizer (Figure 2). The maximum number of leaves per plant (11.67) was calculated from the combination of 7 ton /ha biomass+ $100 \mathrm{~kg} \mathrm{~N} / \mathrm{ha}$ (T1). In contrast, the minimum number of leaves per plant (5.33) was recorded from the control treatment. Okawara et al. (2010) reported that green manure plants increase the number of leaves, plant height, and dry weight of rhizome and yield of rhizome. Akamine et al. (2007) conducted a glasshouse experiment on turmeric and reported that $\mathrm{N}$ increases both growth and yield.

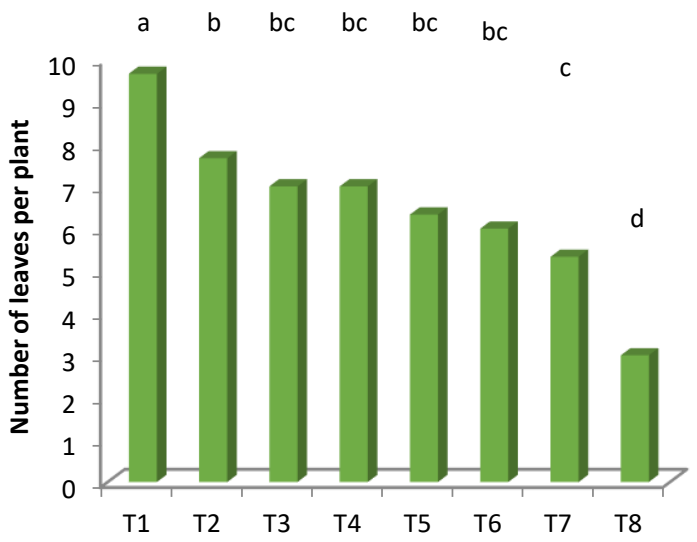

Fig. 3: Effects of Different Combination of Green Manure and Nitrogenous Fertilizer on Number of Leaves per Plant.

\subsection{Leaf length}

Different combination of green manure and nitrogenous fertilizer had significant effect on leaf length. Leaf length was influenced by different combination of green manure and nitrogenous fertilizer (Figure 3). Longest leaf length $(47.33 \mathrm{~cm})$ was found from $100 \mathrm{~kg}$ N/ha while control treatment (T8) produced shortest leaf length $(21.33 \mathrm{~cm})$. All the other treatments showed an intermediate behavior compared to the longest and shortest leaf length. Nitrogen fertilizer ensured favorable condition for the growth of turmeric with optimum cell division and elongation of cell and the ultimate results was the longest leaf. Medda and Hore (2003) found that in combination of $\mathrm{N}$ and $\mathrm{P} 200 \mathrm{~kg}$ per ha produce the longest leaf length $(46.63 \mathrm{~cm})$ of turmeric plant. 


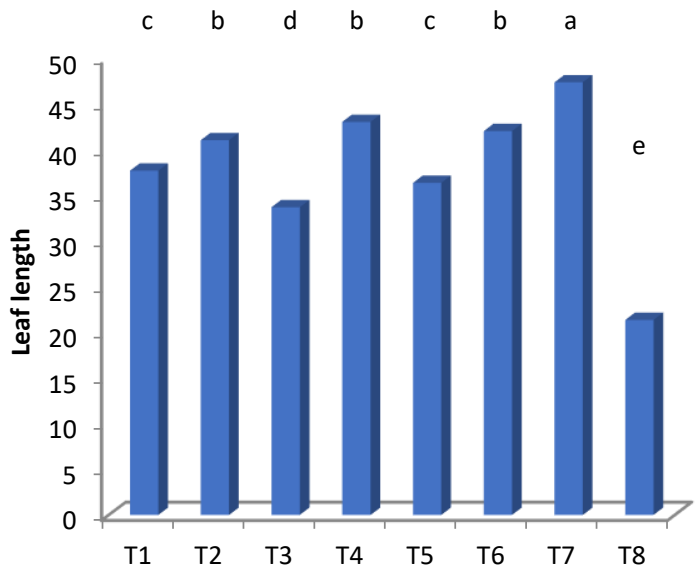

Fig. 3: Effects of Different Combination of Green Manure and Nitrogenous Fertilizer on the Leaf Length of Turmeric Plant.

\subsection{Number of tillers per plant}

Significant variability was found among different levels of green manure and nitrogenous fertilizer in case of number of tillers per plant. Number of tillers was influenced by different combination of green manure and nitrogenous fertilizer (Table 3 ). The maximum number of tillers per plant (7.67) was calculated from the combination of 7 ton /ha biomass $+40 \mathrm{~kg} \mathrm{~N} / \mathrm{ha}$ (T4) followed by second highest number of tillers (6.85) per plant from the combination of 7 ton /ha biomass $+80 \mathrm{~kg} \mathrm{~N} / \mathrm{ha}$ (T2) those are statistically similar. In contrast, the minimum number of tillers per plant (2.00) was recorded from the control treatment (T8). All the other treatments showed an intermediate behavior compared to the highest and lowest number of tillers per plant. This might be the number of tillers per plant was varied with the number of eyes on the seed rhizome. Findings regarding to the number of tillers per plant was agreed to the results of May et al. (2005).

Table 1: Effects of Different Combination of Green Manure and Nitrogenous Fertilizer on the No. of Primary, Secondary and Tertiary Rhizome per Plant

\begin{tabular}{llll}
\hline $\begin{array}{l}\text { Combination of green manure and } \\
\text { nitrogenous fertilizer }\end{array}$ & Number of primary rhizome/plant & $\begin{array}{l}\text { Number of secondary rhi- } \\
\text { zome/plant }\end{array}$ & Number of tertiary rhizome/plant \\
\hline 7 ton /ha biomass+ $100 \mathrm{~kg} \mathrm{~N} / \mathrm{ha}$ & 2.67 & 9.33 & 3.67 \\
7 ton /ha biomass $+80 \mathrm{~kg} \mathrm{~N} / \mathrm{ha}$ & 7.00 & 16.00 & 5.00 \\
7 ton /ha biomass $+60 \mathrm{~kg} \mathrm{~N} / \mathrm{ha}$ & 6.33 & 17.00 & 7.00 \\
7 ton /ha biomass $+40 \mathrm{~kg} \mathrm{~N} / \mathrm{ha}$ & 9.00 & 13.67 & 4.33 \\
7 ton /ha biomass + $20 \mathrm{~kg} \mathrm{~N} / \mathrm{ha}$ & 5.33 & 12.00 & 3.67 \\
7 ton /ha biomass & 4.67 & 11.33 & 3.33 \\
$100 \mathrm{~kg} \mathrm{~N} / \mathrm{ha}$ & 4.67 & 8.33 & 2.33 \\
Control & 3.00 & 5.00 & 1.33 \\
LSD 0.05 value & 1.872 & 2.110 & 1.296 \\
$\mathrm{CV} \%$ & 10.57 & 10.40 & 9.30 \\
Level of significance & $*$ & $*$ & $*$ \\
\hline
\end{tabular}

$*$ denotes significant at the $5 \%$ level of probability.

Table 2: Effects of Different Combination of Green Manure and Nitrogenous Fertilizer on Fresh Weight of Clump, Roots and Rhizomes Per Turmeric Plant Combination of green manure and nitrogenous ferti-

\begin{tabular}{llll}
$\begin{array}{l}\text { Combination of green manure and nitrogenous ferti- } \\
\text { lizer }\end{array}$ & Fresh weight of clump & Fresh weight of roots & Fresh weight of rhizomes \\
\hline 7 ton /ha biomass $+100 \mathrm{~kg} \mathrm{~N} / \mathrm{ha}$ & 145.00 & 39.30 & 226.07 \\
7 ton /ha biomass $+80 \mathrm{~kg} \mathrm{~N} / \mathrm{ha}$ & 179.67 & 46.21 & 244.94 \\
7 ton /ha biomass $+60 \mathrm{~kg} \mathrm{~N} / \mathrm{ha}$ & 159.67 & 40.13 & 252.88 \\
7 ton /ha biomass $+40 \mathrm{~kg} \mathrm{~N} / \mathrm{ha}$ & 189.67 & 41.99 & 277.70 \\
7 ton /ha biomass $+20 \mathrm{~kg} \mathrm{~N} / \mathrm{ha}$ & 123.67 & 36.91 & 207.53 \\
7 ton /ha biomass & 120.33 & 42.97 & 217.44 \\
$100 \mathrm{~kg}$ N/ha & 94.67 & 20.37 & 188.91 \\
Control & 58.00 & 2.295 & 89.01 \\
LSD 0.05 value & 4.118 & 3.32 & 1.737 \\
CV\% & 8.76 & $*$ & 10.47 \\
Level of significance & $*$ & & $*$ \\
\hline
\end{tabular}

* denotes significant at the $5 \%$ level of probability.

Table 3: Effects of Different Combination of Green Manure and Nitrogenous Fertilizer on Dry Weight of Clump, Roots and Rhizomes and Yield of Fresh Rhizomes/ Hectare of Turmeric Plant

\begin{tabular}{|c|c|c|c|c|}
\hline $\begin{array}{l}\text { Combination of green manure and ni- } \\
\text { trogenous fertilizer }\end{array}$ & Dry weight of clump & Dry weight of roots & Dry weight of rhizomes & $\begin{array}{l}\text { Yield of fresh rhizomes per } \\
\text { hectare }\end{array}$ \\
\hline 7 ton $/ \mathrm{ha}$ biomass+ $100 \mathrm{~kg} \mathrm{~N} / \mathrm{ha}$ & 13.07 & 8.03 & 47.12 & 5.49 \\
\hline 7 ton $/$ ha biomass $+80 \mathrm{~kg} \mathrm{~N} / \mathrm{ha}$ & 14.44 & 6.74 & 50.59 & 5.87 \\
\hline 7 ton $/$ ha biomass $+60 \mathrm{~kg} \mathrm{~N} / \mathrm{ha}$ & 16.13 & 7.03 & 58.83 & 5.61 \\
\hline 7 ton $/ \mathrm{ha}$ biomass $+40 \mathrm{~kg} \mathrm{~N} / \mathrm{ha}$ & 20.01 & 9.25 & 69.50 & 6.64 \\
\hline 7 ton $/$ ha biomass $+20 \mathrm{~kg} \mathrm{~N} / \mathrm{ha}$ & 12.23 & 6.94 & 41.37 & 4.54 \\
\hline 7 ton /ha biomass & 12.38 & 6.49 & 46.11 & 4.64 \\
\hline $100 \mathrm{~kg} \mathrm{~N} / \mathrm{ha}$ & 9.67 & 5.30 & 35.93 & 3.36 \\
\hline Control & 7.14 & 3.55 & 30.97 & 3.38 \\
\hline $\mathrm{LSD}_{0.05}$ value & 0.956 & 0.8435 & 1.277 & 0.2769 \\
\hline $\mathrm{CV} \%$ & 4.15 & 7.22 & 9.53 & 10.20 \\
\hline Level of significance & $*$ & $*$ & * & * \\
\hline
\end{tabular}

* denotes significant at the $5 \%$ level of probability.

Table 4: Effects of Different Combination of Green Manure and Nitrogenous Fertilizer on Post-Harvest Soil

\begin{tabular}{|c|c|c|c|c|c|c|}
\hline Treatments & Soil pH & $\mathrm{EC}$ & Total nitrogen $(\%)$ & $\begin{array}{l}\text { Available phosphorus } \\
\text { (ppm) }\end{array}$ & $\begin{array}{l}\text { Available Sulphur } \\
(\mathrm{ppm})\end{array}$ & $\begin{array}{l}\text { Available Potassium } \\
\text { (ppm) }\end{array}$ \\
\hline $\mathrm{T} 1$ & 5.96 & 0.15 & 0.0518 & 10.90 & 77.13 & 190.66 \\
\hline $\mathrm{T} 2$ & 6.31 & 0.22 & 0.0545 & 7.28 & 9.59 & 107.30 \\
\hline $\mathrm{T} 3$ & 4.89 & 0.54 & 0.0505 & 7.75 & 24.15 & 165.60 \\
\hline $\mathrm{T} 4$ & 5.90 & 0.07 & 0.0238 & 9.48 & 8.93 & 126.47 \\
\hline $\mathrm{T} 5$ & 5.28 & 0.45 & 0.0418 & 8.51 & 33.47 & 85.43 \\
\hline
\end{tabular}




\begin{tabular}{lllllll}
\hline T6 & 6.24 & 0.11 & 0.0126 & 7.37 & 15.44 & 31.67 \\
T7 & 5.32 & 0.82 & 0.0256 & 8.63 & 122.60 \\
T8 & 5.81 & 0.28 & 0.0165 & 8.45 & 12.47 & 198.61 \\
\hline
\end{tabular}

\section{Conclusions}

A field experiment was conducted at farmers field of North Jhatibunia, Mirzagonj, Patuakhali to investigate the growth and yield of turmeric (BARI Halud-2), that are suitable to cultivate in coastal region of Bangladesh. The experimental plot was fertilized as per treatment of T1 (7 ton /ha biomass+ $100 \mathrm{~kg} \mathrm{~N} / \mathrm{ha}), \mathrm{T} 2$ (7 ton /ha biomass $+80 \mathrm{~kg} \mathrm{~N} / \mathrm{ha})$, T3 (7 ton /ha biomass $+60 \mathrm{~kg} \mathrm{~N} / \mathrm{ha})$, T4 (7 ton /ha biomass $+40 \mathrm{~kg} \mathrm{~N} / \mathrm{ha}$ ), $\mathrm{T} 5$ (7 ton /ha biomass $+20 \mathrm{~kg} \mathrm{~N} / \mathrm{ha}$ ), T6 (7 ton /ha biomass), T7 (100 kg N/ha) and T8 (Control) with green manure and nitrogenous fertilizer. Data were collected on growth, yield and yield contributing characters. The experiment was laid out in the Randomized Complete Block Design with three replications. Data on different parameters under this investigation were statistically analyzed with 3 replications and the means were compared with Duncan's Multiple Range Test at 5\% level of probability.

\section{Acknowledgement}

Special Thanks to Mohammad Kabirul Islam, Associate Professor, Department of Soil Science, Patuakhali Science and Technology University for his suggestions, guidance, and cooperation.

\section{References}

[1] Akamine H, Hossain M A, Ishimine Y, Yogi K, Hokama K, Iraha Y and Aniya Y 2007: Effects of application of N, P and $\mathrm{K}$ alone or in combination on growth yield and curcumin content of turmeric (Curcuma longaL.). Plant Production Sci. 10(1): 151-154. https://doi.org/10.1626/pps.10.151.

[2] BBS 2013: Report on The Productivity Survey of Turmeric Crop

[3] ICAR- Indian Institute of Spices Research 2015: Kozhikode - 673 012, Kerala.

[4] Ishimine Y, Hossain M A, Ishimine Y and Murayama S 2003: Optimal planting depth for (Curcuma longa L.) cultivation in Darkred soil in Okinawa Island, Southern Japan. Plant Production Science, 6:83-89. https://doi.org/10.1626/pps.6.83.

[5] Jajji Lal 2012: Turmeric, Curcumin and Our Life: A Review. Bull. Environ. Pharmacol. Life Sci.; one (7): 11 - 17.

[6] May a, Cecilio F A B, Cavarianni R L and Barbosa J C 2005: Turmeric (Curcuma longa $L$.) development and productivity in function at nitrogen and potassium doses. Revista Brasileira de Plantas Medicinais. 7(3): 72- 78.

[7] Medda P S and Hore J K 2003: Effects of N and K on the growth and yield of turmeric in alluvial plains of West Bengal. Indian J. of Hort. 60(1): 84-88.

[8] Okawara K, Hossain Md A, Akamine H and Tamaki M 2010: Effects of Green Manure on Growth, Yield and Quality of Turmeric (Curcuma longa L.) Cultivated in Dark-red Soil in Okinawa.

[9] Olejede A O, Iluebbey P and Dixon a G O, 2005: IITA/NRCRI Collaborative Germplasm and Data Collection on root and tuber crops in Nigeria. NRCRI Annual Report. pp: 77-81.

[10] Rahman M A, Zaman M S, Monim M A, Islam a B M S and Sultana N 2010: Effect of fertilizers in combination with organic manure on the yield performance of turmeric. J. Agrofor. Environ. Four (2): 155-158.

[11] Srivastava A 2015: Effect of Some Manure on Quality of Curcuma. Indian Journal of Applied Research, 5.

[12] Swain S C, Rath S and Ray D P 2006: Effect of NPK levels and mulching on yield of turmeric in rainfed uplands. J.Agril. Res. 18(2): 247-250. 